\title{
SLE syndrome, probably induced by labetalol
}

\author{
R. C. Brown \\ M.B., B.Chir., M.R.C.P.
}

\author{
J. COOKE \\ M.Pharm., M.P.S.
}

\author{
M. S. LosowSKY \\ M.D., F.R.C.P.
}

Department of Medicine, St James's University Hospital, Leeds LS9 7TF

\begin{abstract}
Summary
A 45-year-old woman developed polyarthralgia and muscle tenderness after 6 months' therapy with labetalol $1800 \mathrm{mg}$ daily. A raised ANF titre but normal DNA binding levels suggested a drug-induced SLE syndrome. Both symptoms and ANF titre improved when therapy was changed from labetalol to propranolol.
\end{abstract}

\section{Case report}

A woman patient was first treated for hypertension in 1970 when aged 45 years. Her hypertension proved difficult to control and she was treated with combinations of adrenergic neurone-blocking drugs (guanethidine or bethanidine), $\beta$-blockers (propranolol, oxprenolol or atenolol) and thiazide diuretics (bendrofluazide, mefruside or cyclopenthiazide). From February 1978 she was treated with atenolol $200 \mathrm{mg}$ daily and prazosin $4 \mathrm{mg}$ daily, which were discontinued in May 1978 when she developed an urticarial rash. After one month without anti-hypertensive treatment she was admitted to hospital, and labetalol therapy $(300 \mathrm{mg}$ daily) started. The dose was steadily increased to $1800 \mathrm{mg}$ daily by July 1978 , with satisfactory control of blood pressure.

In January 1979 she developed increasingly severe stiffness of the shoulders and upper arms, together with stiffness and swelling of the hands. There was some pain in both knees and elbows, and in the right wrist, but no swelling of these joints. There was no rash, or other symptoms. In May 1979 she was first seen in the clinic with these complaints. The only findings were marked muscle tenderness and stiffness around the shoulders, with crepitus in the left shoulder and wrist and swelling of the left knee. Investigations showed a raised anti-nuclear factor

Address for correspondence: Dr R. C. Brown, Department of Medicine, St James's University Hospital, Leeds LS9 7TF.
(ANF) titre with normal DNA binding, and it was decided in June 1979 to discontinue labetalol therapy. Over a one-month period propranolol was gradually re-introduced and labetalol therapy withdrawn. Blood pressure is now (1980) well controlled by propranolol $1440 \mathrm{mg}$ daily with phenoxybenzamine $20 \mathrm{mg}$ daily and Navidrex-K (Ciba). Muscle stiffness and arthralgia required initial therapy with indomethacin but steadily improved so that by September 1979 there was residual minor stiffness in the left shoulder only, and by January 1980 she was asymptomatic.

Laboratory investigations: $\mathrm{Hb}, \mathrm{WBC}$ and platelet count normal throughout. ESR maximum $26 \mathrm{~mm} / \mathrm{hr}$ (July 1979). Serum immunoglobulins and complement $C_{3}$ and $C_{4}$ components normal (May 1979). DAT screening test negative. Urine - no proteinuria and no red cells. ANF titre and DNA binding (Farr test) - see Table below:

\begin{tabular}{|c|c|c|c|}
\hline & \multicolumn{2}{|c|}{$\begin{array}{l}\text { ANF titre } \\
\text { (reciprocal) }\end{array}$} & $\underset{\text { binding }}{\text { DNA }}$ \\
\hline & $\begin{array}{l}\text { Homo- } \\
\text { geneous }\end{array}$ & Nucleolar & $\begin{array}{l}\text { (norma } \\
<25 \% \text { ) }\end{array}$ \\
\hline May 1979 & 100 & 400 & - \\
\hline June 1979 & 10 & 1600 & 17 \\
\hline July 1979 & 10 & 1600 & 18 \\
\hline September 1979 & 10 & 1600 & 19 \\
\hline October 1979 & 10 & 800 & 18 \\
\hline March 1980 & 50 & 100 & - \\
\hline
\end{tabular}

\section{Discussion}

The polyarthralgia and myalgia, together with the markedly raised ANF titre in the presence of normal DNA binding values are compatible with a druginduced lupus syndrome. Although the patient had been treated with several drugs, her symptoms and raised ANF titre developed after 6 months' treatment with labetalol alone. After withdrawal of labetalol her symptoms cleared and her ANF titre 
has fallen significantly. The authors therefore regard the association between labetalol and the lupus syndrome in this case as probable. This appears to be only the second such case reported (Griffiths and Richardson, 1979), although there are other reports of increases in ANF titre during labetalol therapy in patients who remained asymptomatic (Wilson, 1980). Cases of lupus syndrome are reported to have developed during practolol (Raftery and Denman, 1973) and pindolol therapy (Bensaid, Aldigier and Gualde, 1979), and one possible case developed during propranolol therapy (Harrison, Sisca and Wood, 1976) although in the present patient, as in that of Griffiths and Richardson (1979), the syn- drome improved after the patient was switched from labetalol to propranolol.

\section{References}

Bensaid, J., Aldigier, J-C. \& Gualde, N. (1979) Systemiচ lupus erythematosus syndrome induced by pindolol British Medical Journal, 1, 1603.

GrifFITHS, I.D. \& RichaRDSON, J. (1979) Lupus-like illness associated with labetalol. British Medical Journal, 2, 496

HaRkison, T., Sisca, T.S. \& Wood, W.H. (1976) Propranolol induced lupus syndrome? Postgraduate Medicine, 59, 241 क

RafTery, E.B. \& Denman, A.M. (1973) Systemic lupus ery-ت thematosus syndrome induced by practolol. British Medical Journal, 2, 452.

WiLson, J.D. (1980) Antinuclear antibodies and cardio $\vec{\omega}$ vascular drugs. Drugs, 19, 292. 